\title{
Non small cell lung cancer with targetable driver alterations: Imaging perspective
}

\author{
Eric W Zhang and Subba R Digumarthy* \\ Department of Radiology, Division of Thoracic Imaging and Intervention, Massachusetts General Hospital, USA
}

\begin{abstract}
The discovery of targetable driver alterations has transformed the treatment paradigm in advanced non-small cell lung cancer (NSCLC). Small molecule tyrosine kinase inhibitors have increased survival in the treatment of metastatic NSCLC, and it is now standard of care to screen for targetable driver mutations. The knowledge of imaging findings that are characteristic of specific driver alterations will help to identify, triage, and initiate early treatment in patients. This review will explore the most common driver alterations in NSCLC, the recent advances in targeted therapy, and the characteristic clinical and imaging features.
\end{abstract}

\section{Introduction}

The treatment of advanced non-small cell lung cancer (NSCLC) has dramatically changed with the discovery of driver oncogenes and the development of small molecule tyrosine kinase inhibitors (TKIs) that impede signaling pathways. The change started with discovery of the effectiveness of the TKI gefitinib in the treatment of epidermal growth factor receptor (EGFR)-mutant advanced NSCLC [1,2]. This has sparked the hunt for other oncogene driver alterations and therapeutic agents, and led to discovery of activating chromosomal rearrangements of the anaplastic lymphoma kinase $(A L K)$, receptor tyrosine kinase 1 (ROS1), and rearranged-during-transfection (RET) genes as well as somatic variations in the $\mathrm{V}$-raf murine sarcoma viral oncogene homolog $\mathrm{B}(B R A F)$ and mesenchymal-epithelial transition (MET) genes [3-11]. These discoveries coupled with encouraging results from multiple controlled trials using targeted therapy have led to a paradigm shift in the diagnosis and treatment of advanced NSCLC, whereby it is now routinely recommended to test for actionable driver alterations $[12,13]$. This combination of therapeutics and diagnostics, aptly termed theranostics, represents the progression towards personalized medicine in modern oncology [14,15].

Despite recommendations for routine molecular testing for NSCLC driver oncogenes from both US and European guidelines [12,16], the real-world clinical practice remains suboptimal. A recent multinational study looking into the rates of molecular testing in advanced NSCLC showed substantial variability in percentage of patients undergoing EGFR mutation testing ranging from $41 \%$ in Germany to $97 \%$ in Taiwan, and $A L K$ rearrangement testing was even less, ranging from $23 \%$ in Germany to $3 \%$ in Taiwan [17]. In the United States a recent study demonstrated only $66.9 \%$ of patients underwent $A L K$ testing for advanced NSCLC in community hospitals [18]. This heterogeneity in practice is the result of local differences in drug approval timelines, reimbursement policies, and test panels [17]. Furthermore, testing for NSCLC driver alterations is continuously evolving with no standardized testing platform [19]. Given these roadblocks, it is not surprising that paralleling the rise of precision medicine is an increased interest in radiogenomics, which attempts to define relationships between molecular genomic markers and imaging features [20,21].
By leveraging known clinical and imaging features, the triaging of patients with advanced NSCLC for specific molecular testing and treatment selection can potentially be facilitated [22]. The purpose of this review is to outline the current NSCLC driver alterations, the latest advances in approved and off-label targeted therapies, and most recent developments in NSCLC radiogenomics.

\section{Targeted oncogene therapy}

Underlying the concept of targeted therapy is the idea of oncogenic addiction [23], whereby cancer cells become dependent on specific oncogenes for proliferation and survival. In healthy cells, multiple redundant genes serve similar functions, whereas, in cancer cells, these same genes are often inactivated [23]. As shown in in-vitro studies, inactivation of critical driver oncogenes in cancer cells leads to cellular death due to dysregulated pro-survival and pro-apoptotic signals [24]. The small molecule TKIs and monoclonal antibodies can exploit this intrinsic weakness and are therefore effective in specific oncogenedriven NSCLCs [25].

\section{Epidermal growth factor receptor gene (EGFR)}

Epidermal growth factor receptor $(E G F R)$ is part of tyrosine kinase receptor families responsible for cellular differentiation, proliferation, and anti-apoptosis pathways [26,27]. EGFR is implicated in the activation of ERK MAPK, AKT-PI3K, and PLC- $\gamma 1-P K C$ molecular pathways, which allows for unregulated growth and survival of cancer cells [27]. Though EGFR is overexpressed in up to $80 \%$ of NSCLC [28], only the activating mutations in the EGFR gene are the frequent targets

*Correspondence to: Subba R Digumarthy, Department of Radiology, Massachusetts General Hospital, 55 Fruit Street, Founders 202, Boston, MA 02114, USA, Tel: 617-724-4254, Fax: 617-724-0046, E-mail: sdigumarthy@mgh. harvard.edu

Key words: Non-small cell lung cancer; EGFR; ALK; ROS1; BRAF; driver alterations; radiogenomics; imaging features

Received: November 06, 2019; Accepted: November 21, 2019; Published: November 24, 2019 
for therapy and include TKIs such as erlotinib, gefitinib, and afatinib. The two most prevalent driver mutations of the EGFR gene are L858R missense substitutions and exon 19 deletions [29,30].

The landmark Iressa Pan-Asian Study (IPASS) heralded the use of the TKI gefinitib as first-line treatment in the management of EGFRmutant advanced NSCLC [31]. At the same time, patients with EGFR wild-type fared better with standard chemotherapy than gefitinib [HR 2.85; $\mathrm{P}<0.001$ ], a finding that underlies the importance of early and accurate molecular testing in the treatment of advanced NSCLC [31]. Subsequent clinical trials comparing gefitinib [32-34] as well as other TKIs such as erlotinib [35,36], afatinib [37,38], and osimertinib [39] to chemotherapy as first-line treatment in EGFR-mutated NSCLC have all confirmed findings of improved PFS and superior quality of life.

EGFR mutations are among the most prevalent actionable driver mutations in NSCLC ranging from up to $15 \%$ in Europe, $24 \%$ in the United States, and $47 \%$ in Asia [40,41] and are seen more frequently in Asians, younger populations, and females with minimal smoking history [42-45]. Investigations into imaging features of EGFR-mutant NSCLC have demonstrated several distinguishing features from wildtype EGFR NSCLC, including tumors with more internal cavitations, increased prevalence of air-bronchograms, and increased ground-glass component on computed tomography imaging [46-49]. An important differentiating feature of EGFR mutation adenocarcinomas is the increased frequency of diffuse "miliary-like" lung metastases (Figure 1), an association that has been reported in multiple studies [47,50-52] In the setting of advanced NSCLC with mild or no smoking history, the presence of diffuse lung metastases should raise the index of suspicion for an underlying EGFR mutation and potentially more rapid triaging for molecular testing [52]. In the realm of functional imaging, 18-fluorodeoxyglucose positron emission tomography (18FDG-PET) have demonstrated lower maximum standardized uptake value in EGFR-mutated NSCLC when compared to EGFR wild-type NSCLC [53]. Additionally, preliminary radiomic studies have shown potential in predicting EGFR mutations in NSCLC, although more research is necessary as such techniques have not been standardized in routine clinical practice $[53,54]$.

\section{Anaplastic lymphoma kinase (ALK)}

$A L K$ rearrangements were initially discovered in non-Hodgkin lymphoma in 1994 [55]. In 2007, Soda et al. identified similar $A L K$

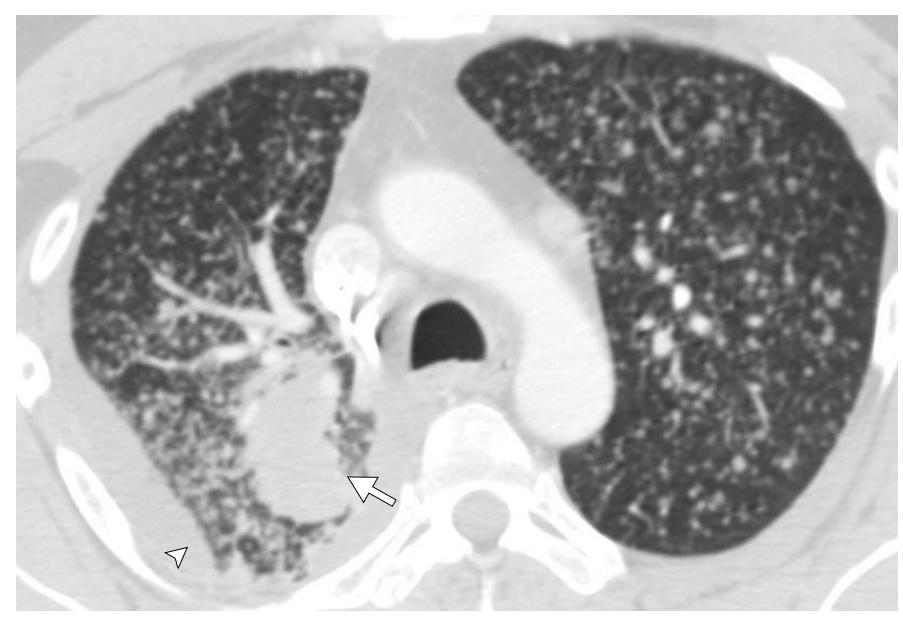

Figure 1. CT image of the chest in lung windows demonstrating presence of diffuse (miliary) lung metastases in EGFR-positive NSCLC. Note the primary lung mass in the posterior right upper lobe (arrow) and small right malignant pleural effusion (arrowhead). rearrangements fusing $A L K$ gene to the echinoderm microtubuleassociated protein-like 4 gene $(E M L 4)$ on chromosome 2 . The expression of this EML-ALK fusion protein aberrantly activates multiple signaling pathways, including P13K/Akt and Ras/Mek/Erk cascades, involved in cellular survival and proliferation [56].

Multiple trials demonstrated the efficacy of TKIs in treating ALKpositive NSCLC. The earliest clinical trials demonstrated improved outcomes using crizotinib as first-line and second-line treatment for ALK-positive advanced NSCLC [57-59]. Subsequent randomized clinical trials demonstrated the superiority of alectinib to crizotinib [60]. Alectinib is now the preferred first-line targeted therapy of advanced $E M L-A L K$ lung cancer [61]. The other agents that are approved include ceritinib, brigatinib, and lorlatinib [62-64]. Lorlatinib is the latest third-generation TKI with potent $A L K$-mutation coverage and CNS penetration [65].

$A L K$-positive NSCLC is found in up to $5 \%$ of lung adenocarcinomas [66]. ALK-positive NSCLC has an earlier age of onset with a median age of 52 years compared to 64 years in wild-type NSCLC [67]. It is interesting to note that $A L K$ rearrangement in other cancers such as anaplastic large cell lymphomas also have early disease onset in children and young adults [56]. There is a strong association between $A L K$ positive NSCLC and light- or never-smoking history. Histologically, the vast majority of EML4-ALK mutations is adenocarcinomas and is more likely than other mutations to be solid tumors containing signet ring cells [68]. Importantly, it has been noted that $A L K$ rearrangements occur largely exclusive from EGFR or KRAS mutations [67,69,70], perhaps related to underlying oncogene addiction.

Much progress has been made recently in the realm of radiogenomics in terms of imaging characteristics of $A L K$-positive NSCLC. The latter is more likely to be solid tumors with fewer propensities for air bronchograms when compared with EGFR-positive tumors. These findings have been reiterated in multiple past studies [71-73] and confirmed on a recently published meta-analysis [74]. The largest study to date on the imaging features of $A L K$-positive NSCLC have also recently demonstrated that these tumors are more likely to be found in the lower lobes and have increased association with sclerotic bone metastases (Figure 2) when compared to EGFR-positive NSCLC. ${ }^{75}$ Furthermore, $A L K$-positive tumors have been found to be more likely associated with distant nodal metastases and lymphangitic spread when compared to EGFR positive tumors $[75,76]$. These novel discoveries have the potential to change management in the care of advanced NSCLC. Although imaging alone will not replace molecular genetic testing, imaging and clinical features of NSCLC can potentially help in the prioritization of testing or re-testing following an inconclusive initial result and expedite initiation of targeted TKIS in patients with ALK-positive NSCLCs [75].

\section{ROS1 rearrangements}

Rearrangement of the receptor tyrosine kinase 1 (ROS1) gene on chromosome 6q22.1 was first implicated in NSCLC in 2007 [3]. Prior to this discovery, ROS translocation had been implicated in glioblastoma [77], with simultaneous discovery of the same genetic alteration in multiple other malignancies such as cholangiocarcinoma, ovarian cancer, and angiosarcoma [78]. Similar to other driver oncogenes, increased ROS signaling has been associated with cellular proliferation and survival with the involvement of the PI3K/AKT, MAPK/ERK, SHP1/2, and JAK/STAT3 signaling pathways [79-81]. Interestingly, the ROS1 gene has been found to be related to $A L K$ on phylogenetic analysis, and this genetic homology likely explains the cross-inhibitory 


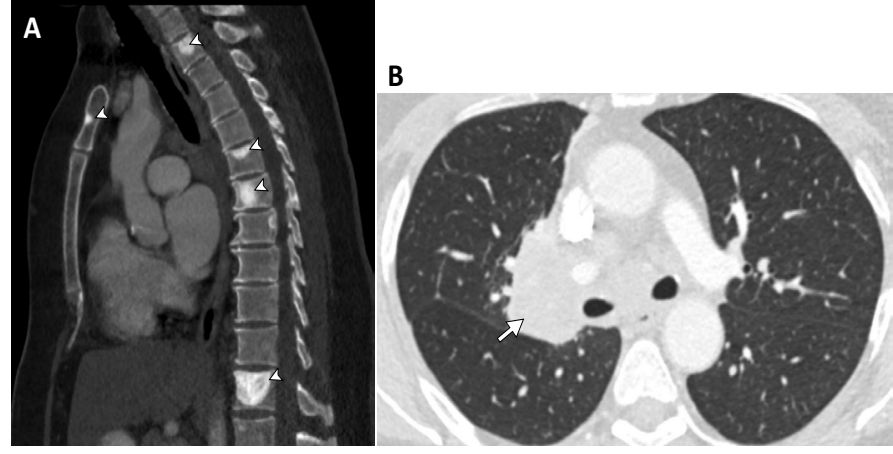

Figure 2. Sagittal and axial CT images of the chest on bone and lung windows in a patien with genotype-proven $A L K$-positive NSCLC. (a) Multiple sclerotic metastases are noted in the vertebral bodies and manubrium (arrowheads). (b) The primary mass is noted in the right inferior hilum (arrow).

activity of several $A L K$-mutation tyrosine kinase inhibitors in ROS1mutation NSCLC [78].

Crizotinib was the first TKI to be approved by the FDA [82] in the treatment of ROS1-rearranged NSCLC in 2016, following the results of the phase 1 PROFILE 1001 study, which demonstrated a disease control rate (DCR) of $90 \%$ and a median progression-free survival (PFS) of 19.2 months [83]. Entrectinib has recently been approved by the FDA [84] for the treatment of ROS1-rearranged NSCLC based in part on results from three clinical trials, demonstrating median PFS of 19.3 months and objective response rate (ORR) of 72 percent [85]. Although not yet approved by the FDA, lorlatinib has also demonstrated efficacy in the treatment of ROS1-mutant NSCLC, with favorable preliminary results [86]. Additional TKIs under research with potential utility in ROS1-positive NSCLC include ceritinib [87], cabozantinib [88], and repotrectinib [89].

ROS-1 rearrangement is found in approximately $1-2 \%$ of NSCLC [90,91]. Comparable to ALK-rearranged NSCLC, ROS1 rearrangement NSCLC is associated with a younger age of onset and is found in predominantly minimal-to-never smokers. Adenocarcinoma histology is also found in the vast majority of cases [7,90]. However, despite these clinicopathologic similarities to ALK-rearranged NSCLC, ROS1rearranged NSCLC has been found to have significantly lower rates of extrathoracic metastases and a lower incidence of brain metastases [92]. These results were recently corroborated in a radiogenomic analysis of ROS1 versus EGFR and ALK mutation NSCLC [93]. Also, ROS1 NSCLC was found to be more associated with lymphangitic carcinomatosis (Figure 3) and sclerotic bone metastases than EGFRmutant NSCLC [93]. Additional studies on the imaging features of ROS1-rearranged NSCLC have noted that primary cancers tend to be located at the periphery of the lungs $[94,95]$.

\section{BRAF mutation}

Mutations in the V-raf murine sarcoma viral oncogene homolog $\mathrm{B}(B R A F)$ gene are relatively uncommon, seen in less than $5 \%$ of NSCLC [11]. BRAF is an effector of the RAS-RAF-MEK-ERK pathway, which regulates cellular survival, growth, and proliferation and is first described in melanoma [96,97]. Approximately half of $B R A F$ mutations in NSCLC are the result of substitution of valine for glutamic acid at codon 600 (V600E) [98]. While historically, BRAF mutations were classified according to the presence or absence of this point mutation, new research has subdivided $B R A F$ mutations into three functional classes related to the degree of $R A F$ kinase activation. Class I mutations are V600-positive and function through monomeric kinase-independent signaling. Class II and III mutations are both V600-negative and with increased kinase signaling in class II mutations or impaired kinase signaling in class III mutations $[99,100]$.

The classification of BRAF-mutation NSCLCs has significant clinicopathologic and prognostic implications. Class I BRAF V600 mutation NSCLC have demonstrated superior progression-free survival when treated with standard chemotherapy agents carboplatin and pemetrexed [101]. Similarly, studies of BRAF V600 mutation small-molecule TKIs have had the most success, due in part to prior clinical trials on the treatment of melanoma [102]. Dabrafenib [103], vemurafenib[104], and combination therapy involving dabrafenib and trametinib $[105,106]$ have all shown promise in class I V600positive mutation NSCLC. Currently, dabrafenib plus trametinib is approved by the FDA for BRAF V600E mutation NSCLC patients who have progressed on chemotherapy. Conversely, the research on BRAF non-V600 mutation NSCLC has been less encouraging with insufficient data to draw any major conclusions [107]. Unsurprisingly, the prognosis of non-V600 mutation NSCLC is significantly worse than V600 mutation NSCLC with a three-year survival of 24 percent in V600 mutation NSCLC versus 0 percent in non-V600 mutation [108]. From a clinical perspective, V600 mutation patients are more likely to be minimal- or never-smokers when compared to non-V600 mutation patients [108]. A recent study on the imaging features of $B R A F$ mutations showed that the majority of such tumors were solid
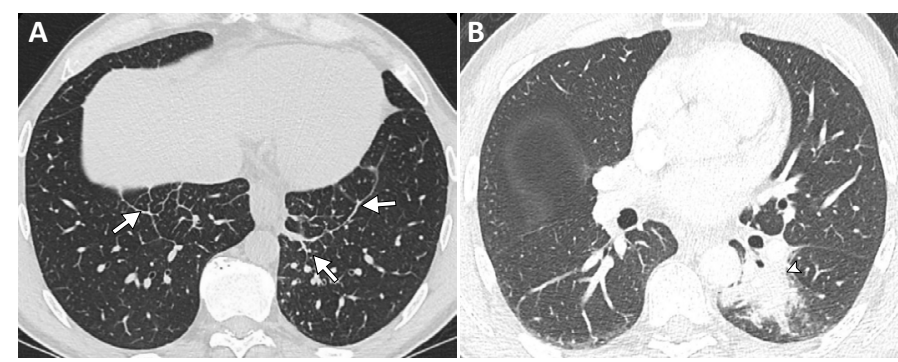

Figure 3. Axial CT images of the chest in lung windows at the lung bases and at the level of the midlung in a patient with genotype-proven ROS1-positive NSCLC. (a) Increased nodular interlobular septal thickening at the lung bases in keeping with worsening lymphangitic carcinomatosis (arrows). (b) The primary mass is seen in the superior segment of the left lower lobe (arrowhead).
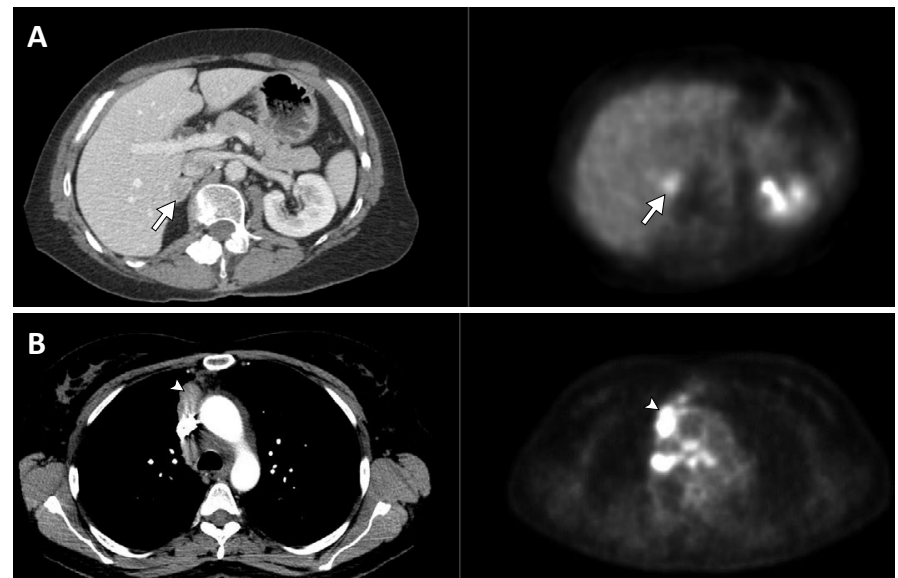

Figure 4. Axial CT images of the chest and abdomen on soft-tissue windows and accompanying 18F-fluorodeoxyglucose positron emission tomography (18F-FDG PET) images in two different patients with genotype-proven BRAF-positive NSCLC. (a) Images of V600-negative $B R A F$ NSCLC demonstrating solitary right adrenal metastasis with increased uptake on FDG-PET (arrows). (b) Images of V600-positive BRAF NSCLC demonstrating multiple intrathoracic metastases along the right mediastinal pleura (arrowheads) and in multiple mediastinal lymph nodes, with increased uptake on FDG-PET. 
and mass-like. The authors demonstrated no significant difference in imaging features between the three functional classes of BRAFmutation. Intrathoracic metastases and pleural involvement was found to be more common in class I mutation tumors compared to class II or III, whereas the latter had an increased propensity for intra-abdominal spread (Figure 4) [109].

\section{Other targetable mutations}

While TKIs have all been approved by the FDA in the front-line treatment of EGFR, $A L K, R O S 1$, and BRAF-positive NSCLCs [12], there exist many other potentially targetable driver mutations in NSCLC, with much ongoing research in this domain. The most promising of oncogenic drivers include amplification of the mesenchymal-epithelial transition $(M E T)$ factor, rearrangement of the rearranged during transfection $(R E T)$, and mutations of the human epidermal growth factor 2 (HER2) genes. Current clinical trials involving these driver alterations have been either inconclusive or negative to date, with off-label usage of tyrosine kinase inhibitors and immunomodulators $[15,110]$. Similarly, there is currently a paucity of radiogenomic research on the imaging features of these particular driver mutations.

\section{Conclusion}

The groundbreaking discovery of specific driver alterations in NSCLC also lead to the discovery and adoption of small-molecule tyrosine kinase inhibitors for the treatment of advanced NSCLC. The clinicopathologic and radiogenomic studies documented significant differences in clinical presentation, patterns of metastases, and imaging features among the different driver mutations in NSCLC. Although not as specific as molecular genotyping, these clinical and radiogenomic characteristics can help in triaging patients for appropriate test selection, expedited diagnosis and therapy, and repeat genotyping in the event of discordant results. The emergence of a multitude of new driver oncogenes means that more research is needed on all fronts.

\section{Conflict of interest}

Funding: This research did not receive any specific grant from funding agencies in the public, commercial, or not-for-profit sectors.

The authors have no conflicts of interest related to this work. Other disclosures (not related to this work) are below:

\section{EWZ: No relevant disclosures.}

SRD: Provides independent image analysis for hospital contracted clinical research trials programs for Merck, Pfizer, Bristol Mayer Squibb, Novartis, Roche, Polaris, Cascadian, Abbvie, Gradalis, Clinical Bay, Zai laboratories. Received honorarium from: Siemens, not related to work.

\section{References}

1. Lynch TJ, Bell DW, Sordella R, Gurubhagavatula S, Okimoto RA, et al. (2004) Activating mutations in the epidermal growth factor receptor underlying responsiveness of non-small-cell lung cancer to gefitinib. N Engl J Med 350: 2129-2139. [Crossref]

2. Paez JG, Jänne PA, Lee JC, Tracy S, Greulich H, et al. (2004) EGFR mutations in lung cancer: correlation with clinical response to gefitinib therapy. Science 304: 1497-1500. [Crossref]

3. Rikova K, Guo A, Zeng Q, Possemato A, Yu J, et al. (2007) Global survey of phosphotyrosine signaling identifies oncogenic kinases in lung cancer. Cell 131: 11901203. [Crossref]

4. Soda M, Choi YL, Enomoto M, Takada S, Yamashita Y, et al. (2007) Identification of the transforming EML4-ALK fusion gene in non-small-cell lung cancer. Nature 448: 561-566. [Crossref]
5. Pao W, Girard N (2011) New driver mutations in non-small-cell lung cancer. Lancet Oncol 12: 175-180. [Crossref]

6. Shaw AT, Hsu PP, Awad MM, Engelman JA (2013) Tyrosine kinase gene rearrangements in epithelial malignancies. Nat Rev Cancer 13: 772-787. [Crossref]

7. Takeuchi K, Soda M, Togashi Y, Suzuki R, Sakata S, et al. (2012) RET, ROS1 and ALK fusions in lung cancer. Nat Med 18: 378-381. [Crossref]

8. Janku F, Garrido-Laguna I, Petruzelka LB, Stewart DJ, Kurzrock R (2011) Novel therapeutic targets in non-small cell lung cancer. $J$ Thorac Oncol 6: 1601-1612. [Crossref]

9. Guin S, Ru Y, Wynes MW, Mishra R, Lu X, et al. (2013) Contributions of KRAS and RAL in non-small-cell lung cancer growth and progression. $J$ Thorac Oncol 8: 1492 1501. [Crossref]

10. Sattler M1, Reddy MM, Hasina R, Gangadhar T, Salgia R (2011) The role of the c-Me pathway in lung cancer and the potential for targeted therapy. Ther Adv Med Oncol 3: 171-184. [Crossref]

11. Marchetti A1, Felicioni L, Malatesta S, Grazia Sciarrotta M, et al. (2011) Clinica features and outcome of patients with non-small-cell lung cancer harboring BRAF mutations. J Clin Oncol 29: 3574-3579. [Crossref]

12. Ettinger DS, Aisner DL, Wood DE, Akerley W, Bauman J, et al. (2018) NCCN Guidelines Insights: Non-Small Cell Lung Cancer, Version 5.2018. J Natl Compr Canc Netw 16: 807-821. [Crossref]

13. Lindeman NI, Cagle PT, Aisner DL, Arcila ME, Beasley MB, et al. (2018) Updated Molecular Testing Guideline for the Selection of Lung Cancer Patients for Treatmen With Targeted Tyrosine Kinase Inhibitors: Guideline From the College of American Pathologists, the International Association for the Study of Lung Cancer, and the Association for Molecular Pathology. Arch Pathol Lab Med 142: 321-346. [Crossref]

14. Hanahan D, Weinberg RA (2011) Hallmarks of cancer: the next generation. Cell 144 646-674. [Crossref]

15. Chan BA, Hughes BG (2015) Targeted therapy for non-small cell lung cancer: curren standards and the promise of the future. Translational lung cancer research 4: 36-54. [Crossref]

16. Planchard D, Popat S, Kerr K, Novello S, Smit EF, et al. (2018) Metastatic non-small cell lung cancer: ESMO Clinical Practice Guidelines for diagnosis, treatment and follow-up. Ann Oncol 29: iv192-iv237. [Crossref]

17. Lee DH, Tsao MS, Kambartel KO, Isobe H, Huang MS, et al. (2018) Molecular testing and treatment patterns for patients with advanced non-small cell lung cancer: PIvOTAL observational study. PloS one 13: e0202865. [Crossref]

18. (2018) ALK Testing Trends and Patterns Among Community Practices in the United States. JCO Precision Oncology: 1-11.

19. Garinet S, Laurent-Puig P, Blons H, Oudart JB (2018) Current and Future Molecular Testing in NSCLC, What Can We Expect from New Sequencing Technologies? J Clin Med 7. [Crossref]

20. Rutman AM, Kuo MD (2009) Radiogenomics: creating a link between molecular diagnostics and diagnostic imaging. Eur J Radiol 70: 232-241. [Crossref]

21. Kuo MD, Jamshidi N (2014) Behind the numbers: Decoding molecular phenotypes with radiogenomics--guiding principles and technical considerations. Radiology 270: 320-325. [Crossref]

22. Mazurowski MA (2015) Radiogenomics: what it is and why it is important. $J$ Am Coll Radiol 12: 862-866. [Crossref]

23. Weinstein IB, Joe A (2008) Oncogene addiction. Cancer Res 68: 3077-3080. [Crossref]

24. Sharma SV, Gajowniczek P, Way IP, Lee DY, Jiang J, et al. (2006) A common signaling cascade may underlie "addiction" to the Src, BCR-ABL, and EGF receptor oncogenes. Cancer Cell 10: 425-435. [Crossref]

25. Torti D, Trusolino L (2011) Oncogene addiction as a foundational rationale for targeted anti-cancer therapy: promises and perils. EMBO Mol Med 3: 623-636. [Crossref]

26. Arteaga CL (2001) The epidermal growth factor receptor: from mutant oncogene in nonhuman cancers to therapeutic target in human neoplasia. J Clin Oncol 19: 32S-40S. [Crossref]

27. Wee P, Wang Z (2007) Epidermal Growth Factor Receptor Cell Proliferation Signaling Pathways. Cancers (Basel) 9. [Crossref]

28. Veale D, Ashcroft T, Marsh C, Gibson GJ, Harris AL (1987) Epidermal growth factor receptors in non-small cell lung cancer. Br J Cancer 55: 513-516. [Crossref] 
29. Yarden Y, Sliwkowski MX (2001) Untangling the ErbB signalling network. Nat Rev Mol Cell Biol 2: 127-137. [Crossref]

30. Jackman DM, Yeap BY, Sequist LV, Lindeman N, Holmes AJ, et al. (2006) Exon 19 deletion mutations of epidermal growth factor receptor are associated with prolonged survival in non-small cell lung cancer patients treated with gefitinib or erlotinib. Clin Cancer Res 12: 3908-3914. [Crossref]

31. Mok TS, Wu YL, Thongprasert S, Yang CH, Chu DT, et al. (2009) Gefitinib or carboplatinpaclitaxel in pulmonary adenocarcinoma. NEng J Med 361: 947-957. [Crossref]

32. Maemondo M, Inoue A, Kobayashi K, Sugawara S, Oizumi S, et al. (2010) Gefitinib or chemotherapy for non-small-cell lung cancer with mutated EGFR. $N$ Eng J Med 362: 2380-2388. [Crossref]

33. Mitsudomi 1, Morita S, Yatabe Y, Negoro S, Okamoto I, et al. (2010) Gefitinib versus cisplatin plus docetaxel in patients with non-small-cell lung cancer harbouring mutations of the epidermal growth factor receptor (WJTOG3405): an open label, randomised phase 3 trial. Lancet Oncol 11: 121-128. [Crossref]

34. Han JY1, Park K, Kim SW, Lee DH, Kim HY, et al. (2012) First-SIGNAL: firstline single-agent iressa versus gemcitabine and cisplatin trial in never-smokers with adenocarcinoma of the lung. J Clin Oncol 30: 1122-1128. [Crossref]

35. Zhou C, Wu YL, Chen G, Feng J, Liu XQ, et al. (2011) Erlotinib versus chemotherapy as first-line treatment for patients with advanced EGFR mutation-positive non-smallcell lung cancer (OPTIMAL, CTONG-0802): a multicentre, open-label, randomised, phase 3 study. Lancet Oncol 12: 735-742. [Crossref]

36. Rosell R1, Carcereny E, Gervais R, Vergnenegre A, Massuti B, et al. (2012) Erlotinib versus standard chemotherapy as first-line treatment for European patients with advanced EGFR mutation-positive non-small-cell lung cancer (EURTAC): a multicentre, open-label, randomised phase 3 trial. Lancet Oncol 13: 239-246. [Crossref]

37. Sequist LV, Yang JC, Yamamoto N, O'Byrne K, Hirsh V, et al. (2013) Phase III study of afatinib or cisplatin plus pemetrexed in patients with metastatic lung adenocarcinoma with EGFR mutations. J Clin Oncol 31: 3327-3334. [Crossref]

38. Wu YL, Zhou C, Hu CP, Feng J, Lu S, et al. (2014) Afatinib versus cisplatin plus gemcitabine for first-line treatment of Asian patients with advanced non-small-cell lung cancer harbouring EGFR mutations (LUX-Lung 6): an open-label, randomised phase 3 trial. Lancet Oncol 15: 213-222. [Crossref]

39. Soria JC, Ohe Y, Vansteenkiste J, Reungwetwattana T, Chewaskulyong B, et al. (2018) Osimertinib in Untreated EGFR-Mutated Advanced Non-Small-Cell Lung Cancer. $N$ Engl J Med 378: 113-125. [Crossref]

40. Midha A, Dearden S, McCormack R (2015) EGFR mutation incidence in non-smallcell lung cancer of adenocarcinoma histology: a systematic review and global map by ethnicity (mutMapII). Am J Cancer Res 5: 2892-2911. [Crossref]

41. Zhang YL, Yuan JQ, Wang KF, Fu XH, Han XR, et al. (2016) The prevalence of EGFR mutation in patients with non-small cell lung cancer: a systematic review and metaanalysis. Oncotarget 7: 78985-78993. [Crossref]

42. Shi Y, Au JS, Thongprasert S, Srinivasan S, Tsai CM, et al. (2014) A prospective, molecular epidemiology study of EGFR mutations in Asian patients with advanced non-small-cell lung cancer of adenocarcinoma histology (PIONEER). $J$ Thorac Oncol 9: 154-162. [Crossref]

43. Fukuoka M1, Yano S, Giaccone G, Tamura T, Nakagawa K, et al. (2003) Multiinstitutional randomized phase II trial of gefitinib for previously treated patients with advanced non-small-cell lung cancer (The IDEAL 1 Trial) [corrected]. J Clin Oncol 21: 2237-2246. [Crossref]

44. Pérez-Soler R, Chachoua A, Hammond LA, Rowinsky EK, Huberman M, et al. (2004) Determinants of tumor response and survival with erlotinib in patients with non--smallcell lung cancer. J Clin Oncol 22: 3238-3247. [Crossref]

45. Kim ES, Hirsh V, Mok T, Socinski MA, Gervais R, et al. (2008) Gefitinib versus docetaxel in previously treated non-small-cell lung cancer (INTEREST): a randomised phase III trial. Lancet 372: 1809-1818. [Crossref]

46. Lee HJ, Kim YT, Kang CH, Zhao B, Tan Y, et al. (2013) Epidermal growth factor receptor mutation in lung adenocarcinomas: relationship with $\mathrm{CT}$ characteristics and histologic subtypes. Radiology 268: 254-264. [Crossref]

47. Hasegawa M, Sakai F, Ishikawa R, Kimura F, Ishida H, et al. (2016) CT Features of Epidermal Growth Factor Receptor-Mutated Adenocarcinoma of the Lung: Comparison with Nonmutated Adenocarcinoma. J Thorac Oncol 11: 819-826. [Crossref]

48. Rizzo S, Petrella F, Buscarino V, De Maria F, Raimondi S, et al. (2016) CT Radiogenomic Characterization of EGFR, K-RAS, and ALK Mutations in Non-Small Cell Lung Cancer. Eur Radiol 26: 32-42. [Crossref]
49. Zhang H, Cai W, Wang Y, Liao M, Tian S (2019) CT and clinical characteristics that predict risk of EGFR mutation in non-small cell lung cancer: a systematic review and meta-analysis. Int J Clin Oncol 24: 649-659. [Crossref]

50. Hsu F, Nichol A, Toriumi T, De Caluwe A (2017) Miliary metastases are associated with epidermal growth factor receptor mutations in non-small cell lung cancer: a population-based study. Acta Oncol 56: 1175-1180. [Crossref]

51. Togashi Y, Masago K, Kubo T, Sakamori Y, Kim YH, et al. (2011) Association of diffuse, random pulmonary metastases, including miliary metastases, with epidermal growth factor receptor mutations in lung adenocarcinoma. Cancer 117: 819-825. [Crossref]

52. Digumarthy SR, Mendoza DP, Padole A, Chen T, Peterson PG, et al. (2019) Diffuse Lung Metastases in EGFR-Mutant Non-Small Cell Lung Cancer. Cancers (Basel) 11. [Crossref]

53. Mak RH, Digumarthy SR, Muzikansky A, Engelman JA, Shepard JA, et al. (2011) Role of $18 \mathrm{~F}$-fluorodeoxyglucose positron emission tomography in predicting epidermal growth factor receptor mutations in non-small cell lung cancer. Oncologist 16: 319326. [Crossref]

54. Digumarthy SR, Padole AM, Gullo RL, Sequist LV, Kalra MK (2019) Can CT radiomic analysis in NSCLC predict histology and EGFR mutation status? Medicine (Baltimore) 98: e13963. [Crossref]

55. Morris SW, Kirstein MN, Valentine MB, Dittmer KG, Shapiro DN, et al. (1994) Fusion of a kinase gene, ALK, to a nucleolar protein gene, NPM, in non-Hodgkin's lymphoma. Science 263: 1281-1284. [Crossref]

56. Shaw AT, Solomon B (2011) Targeting anaplastic lymphoma kinase in lung cancer. Clin Cancer Res 17: 2081-2086. [Crossref]

57. Solomon BJ, Mok T, Kim DW, Wu YL, Nakagawa K, et al. (2014) First-line crizotinib versus chemotherapy in ALK-positive lung cancer. $N$ Engl J Med 371: 2167-2177. [Crossref]

58. Shaw AT, Kim DW, Nakagawa K, Seto T, Crinó L, et al. (2013) Crizotinib versus chemotherapy in advanced ALK-positive lung cancer. $N$ Engl J Med 368: 2385-2394. [Crossref]

59. Solomon BJ, Kim DW, Wu YL, Nakagawa K, Mekhail T, et al. (2018) Final Overall Survival Analysis From a Study Comparing First-Line Crizotinib Versus Chemotherapy in ALK-Mutation-Positive Non-Small-Cell Lung Cancer. J Clin Oncol 36: 2251-2258. [Crossref]

60. Peters S, Camidge DR, Shaw AT, Gadgeel S, Ahn JS, et al. (2017) Alectinib versus Crizotinib in Untreated ALK-Positive Non-Small-Cell Lung Cancer. $N$ Engl J Med 377: 829-838. [Crossref]

61. Alectinib capsules, for oral use. United States Prescribing Information. US National Library of Medicine. [https://www.accessdata.fda.gov/drugsatfda_docs/ label/2018/208434s004lbl.pdf] (Accessed on November 3, 2019).

62. Soria JC, Tan DSW, Chiari R, Wu YL, Paz-Ares L, et al. (2017) First-line ceritinib versus platinum-based chemotherapy in advanced ALK-rearranged non-small-cell lung cancer (ASCEND-4): a randomised, open-label, phase 3 study. Lancet 389: 917-929. [Crossref]

63. Ceritinib capsules. United States Prescribing Information. US National Library of Medicine. [http://www.accessdata.fda.gov/drugsatfda_docs/label/2017/205755s009lbl. pdf] (Accessed on November 3, 2019).

64. Camidge DR, Kim HR, Ahn MJ, Yang JC, Han JY, et al. (2018) Brigatinib versus Crizotinib in ALK-Positive Non-Small-Cell Lung Cancer. N Engl J Med 379: 2027 2039. [Crossref]

65. Solomon BJ, Besse B, Bauer TM, Felip E, Soo RA, et al. (2018) Lorlatinib in patients with ALK-positive non-small-cell lung cancer: results from a global phase 2 study. Lancet Oncol 19: 1654-1667. [Crossref]

66. Pikor LA, Ramnarine VR, Lam S, Lam WL (2013) Genetic alterations defining NSCLC subtypes and their therapeutic implications. Lung Cancer 82: 179-189. [Crossref]

67. Shaw AT, Yeap BY, Mino-Kenudson M, Digumarthy SR, Costa DB, et al. (2009) Clinical features and outcome of patients with non-small-cell lung cancer who harbor EML4-ALK. J Clin Oncol 27: 4247-4253. [Crossref]

68. Rodig SJ, Mino-Kenudson M, Dacic S, Yeap BY, Shaw A, et al. (2009) Unique clinicopathologic features characterize ALK-rearranged lung adenocarcinoma in the western population. Clin Cancer Res 15: 5216-5223. [Crossref]

69. Zhang X, Zhang S, Yang X, Yang J, Zhou Q, et al. (2010) Fusion of EML4 and ALK is associated with development of lung adenocarcinomas lacking EGFR and KRAS mutations and is correlated with ALK expression. Mol Cancer 9: 188. [Crossref] 
70. Takahashi 1, Sonobe M, Kobayashi M, Yoshizawa A, Menju T, et al. (2010) Clinicopathologic features of non-small-cell lung cancer with EML4-ALK fusion gene. Ann Surg Oncol 17: 889-897. [Crossref]

71. Liu Y, Kim J, Qu F, Liu S, Wang H, et al. (2016) CT Features Associated with Epidermal Growth Factor Receptor Mutation Status in Patients with Lung Adenocarcinoma. Radiology 280: 271-280. [Crossref]

72. Park J, Kobayashi Y, Urayama KY, Yamaura H, Yatabe Y, et al. (2016) Imaging Characteristics of Driver Mutations in EGFR, KRAS, and ALK among TreatmentNaive Patients with Advanced Lung Adenocarcinoma. PloS one 11: e0161081. [Crossref]

73. Kim TJ, Lee CT, Jheon SH, Park JS, Chung JH (2016) Radiologic Characteristics of Surgically Resected Non-Small Cell Lung Cancer With ALK Rearrangement or EGFR Mutations. Ann Thorac Surg 101: 473-480. [Crossref]

74. Mendoza DP, Stowell J, Muzikansky A, Shepard JO, Shaw AT, et al. (2019) Computed Tomography Imaging Characteristics of Non-Small-Cell Lung Cancer With Anaplastic Lymphoma Kinase Rearrangements: A Systematic Review and Meta-Analysis. Clin Lung Cancer 20: 339-349. [Crossref]

75. Mendoza DP, Lin JJ, Rooney MM, Chen T, Sequist LV, et al. (2019) Imaging features and metastatic patterns of advanced ALK-positive non-small cell lung cancer. ARJ Am J Roentgenol. [Crossref]

76. Choi CM, Kim MY, Hwang HJ, Lee JB, Kim WS (2015) Advanced adenocarcinoma of the lung: comparison of CT characteristics of patients with anaplastic lymphoma kinase gene rearrangement and those with epidermal growth factor receptor mutation. Radiology 275: 272-279. [Crossref]

77. Birchmeier C, Sharma S, Wigler M (1987) Expression and rearrangement of the ROS1 gene in human glioblastoma cells. Proc Natl Acad Sci U S A 84: 9270-9274. [Crossref]

78. Lin JJ, Shaw AT (2017) Recent Advances in Targeting ROS1 in Lung Cancer. J Thorac Oncol12: 1611-1625. [Crossref]

79. Jun HJ, Johnson H, Bronson RT, de Feraudy S, White F, et al. (2012) The oncogenic lung cancer fusion kinase CD74-ROS activates a novel invasiveness pathway through E-Syt1 phosphorylation. Cancer Res 72: 3764-3774. [Crossref]

80. Davies KD, Le AT, Theodoro MF, Skokan MC, Aisner DL, et al. (2012) Identifying and targeting ROS1 gene fusions in non-small cell lung cancer. Clin Cancer Res 18: 4570-4579. [Crossref]

81. Charest A1, Wilker EW, McLaughlin ME, Lane K, Gowda R, et al. (2006) ROS fusion tyrosine kinase activates a SH2 domain-contai $/ 1 / \mathrm{m}, \mathrm{mk} ; 91 . ; ; . . . n i \backslash n g$ phosphatase-2/ phosphatidylinositol 3-kinase/mammalian target of rapamycin signaling axis to form glioblastoma in mice. Cancer Res 66: 7473-7481. [Crossref]

82. Crizotinib capsules, for oral use. United States Prescribing Information. US National Library of Medicine. [http://www.accessdata.fda.gov/drugsatfda_docs/ label/2016/202570s017lbl.pdf] (Accessed on November 1, 2019).

83. Shaw AT, Ou SH, Bang YJ, Camidge DR, Solomon BJ, et al. (2014) Crizotinib in ROS1-rearranged non-small-cell lung cancer. N Engl J Med 371: 1963-1971. [Crossref]

84. Entrectinib capsules, for oral use. United States Prescribing Information. US National Library of Medicine. [https://www.accessdata.fda.gov/drugsatfda_docs/ label/2019/212725s000lbl.pdf] (Accessed on November 3, 2019).

85. Siena S, Doebele RC, Shaw AT, Karapetis CS, Tan DS, et al. (2019) Efficacy of entrectinib in patients (pts) with solid tumors and central nervous system (CNS) metastases: Integrated analysis from three clinical trials. $J$ Clin Oncol 37S: ASCO \#3017.

86. Ou S, Shaw A, Riely G, Chiari R, Bauman J, et al. (2018) Clinical Activity of Lorlatinib in Patients with ROS1+ Advanced Non-Small Cell Lung Cancer: Phase 2 Study Cohort EXP-6. J Thorac Oncol 13S: WCLC \#OA02.03.

87. Lim SM, Kim HR, Lee JS, Lee KH, Lee YG, et al. (2017) Open-Label, Multicenter, Phase II Study of Ceritinib in Patients With Non-Small-Cell Lung Cancer Harboring ROS1 Rearrangement. J Clin Oncol 35: 2613-2618. [Crossref]

88. Drilon A, Somwar R, Wagner JP, Vellore NA, Eide CA, et al. (2016) A Novel CrizotinibResistant Solvent-Front Mutation Responsive to Cabozantinib Therapy in a Patient with ROS1-Rearranged Lung Cancer. Clin Cancer Res 22: 2351-2358. [Crossref]

89. Cho BC, Drilon AE, Doebele RC, Kim DW, Lin JJ, et al. (2018) Safety and preliminary clinical activity of ropotrectinib (TPX-0005) aRTLi, in advanced ROS1 fusion-positive NSCLC. J Thorac Oncol 13S: WCLC \#OA2.02.

90. Bergethon K, Shaw AT, Ou SH, Katayama R, Lovly CM, et al. (2012) ROS1 rearrangements define a unique molecular class of lung cancers. J Clin Oncol 30: 863870. [Crossref]
91. Cancer Genome Atlas Research Network (2014) Comprehensive molecular profiling of lung adenocarcinoma. Nature 511: 543-550. [Crossref]

92. Gainor JF, Tseng D, Yoda S, Dagogo-Jack I, Friboulet L, et al. (2017) Patterns of Metastatic Spread and Mechanisms of Resistance to Crizotinib in ROS1-Positive NonSmall-Cell Lung Cancer. JCO Precis Oncol 2017. [Crossref]

93. Digumarthy SR, Mendoza DP, Lin JJ, Chen T, Rooney MM, et al. (2019) Computed Tomography Imaging Features and Distribution of Metastases in ROS1-rearranged Non-Small-cell Lung Cancer. Clin Lung Cancer. [Crossref]

94. Yoon HJ, Sohn I, Cho JH, Lee HY, Kim JH, et al. (2015) Decoding Tumor Phenotype for ALK, ROS1, and RET Fusions in Lung Adenocarcinoma Using a Radiomics Approach. Medicine (Baltimore) 94: e1753. [Crossref]

95. Plodkowski AJ, Drilon A, Halpenny DF, O'Driscoll D, Blair D, et al. (2015) From genotype to phenotype: Are there imaging characteristics associated with lung adenocarcinomas harboring RET and ROS1 rearrangements? Lung Cancer 90: 321325. [Crossref]

96. Davies H1, Bignell GR, Cox C, Stephens P, Edkins S, et al. (2002) Mutations of the BRAF gene in human cancer. Nature 417: 949-954. [Crossref]

97. Wan PT, Garnett MJ, Roe SM, Lee S, Niculescu-Duvaz D, et al. (2004) Mechanism of activation of the RAF-ERK signaling pathway by oncogenic mutations of B-RAF. Cell 116: 855-867. [Crossref]

98. Baik CS, Myall NJ, Wakelee HA (2017) Targeting BRAF-Mutant Non-Small Cel Lung Cancer: From Molecular Profiling to Rationally Designed Therapy. Oncologist 22: 786-796. [Crossref]

99. Yao Z, Torres NM, Tao A, Gao Y, Luo L, et al. (2015) BRAF Mutants Evade ERKDependent Feedback by Different Mechanisms that Determine Their Sensitivity to Pharmacologic Inhibition. Cancer Cell 28: 370-383. [Crossref]

100. Yao Z, Yaeger R, Rodrik-Outmezguine VS, Tao A, Torres NM, et al. (2017) Tumours with class 3 BRAF mutants are sensitive to the inhibition of activated RAS. Nature 548: 234-238. [Crossref]

101. Dagogo-Jack I, Martinez P, Yeap BY, Ambrogio C, Ferris LA, et al. (2019) Impact of BRAF Mutation Class on Disease Characteristics and Clinical Outcomes in BRAFmutant Lung Cancer. Clin Cancer Res 25: 158-165. [Crossref]

102. Chapman PB, Hauschild A, Robert C, Haanen JB, Ascierto P, et al. (2011) Improved survival with vemurafenib in melanoma with BRAF V600E mutation. $N$ Engl $J$ Med 364: 2507-2516. [Crossref]

103. Planchard D, Kim TM, Mazieres J, Quoix E, Riely G, et al. (2016) Dabrafenib in patients with BRAF(V600E)-positive advanced non-small-cell lung cancer: a singlearm, multicentre, open-label, phase 2 trial. Lancet Oncol 17: 642-650. [Crossref]

104. (2015) Vemurafenib in Multiple Nonmelanoma Cancers with BRAF V600 Mutations. N Engl J Med 373: 726-736. [Crossref]

105. Planchard D, Smit EF, Groen HJM, Mazieres J, Besse B, et al. (2016) Dabrafenib plus trametinib in patients with previously treated BRAF(V600E)-mutant metastatic non-small cell lung cancer: an open-label, multicentre phase 2 trial. Lancet Oncol 17 984-993. [Crossref]

106. Planchard D, Smit EF, Groen HJM, Mazieres J, Besse B, et al. (2017) Dabrafenib plus trametinib in patients with previously untreated BRAF(V600E)-mutant metastatic non-small-cell lung cancer: an open-label, phase 2 trial. Lancet Oncol 18 : 1307-1316. [Crossref]

107. Alvarez JGB, Otterson GA (2019) Agents to treat BRAF-mutant lung cancer. Drugs Context 8: 212566. [Crossref]

108. Litvak AM1, Paik PK, Woo KM, Sima CS, Hellmann MD, et al. (2014) Clinical characteristics and course of 63 patients with BRAF mutant lung cancers. $J$ Thorac Oncol 9: 1669-1674. [Crossref]

109. Mendoza DP, Dagogo-Jack I, Chen T, Padole A, Shepard JO, et al. (2019) Imaging characteristics of BRAF-mutant non-small cell lung cancer by functional class. Lung Cancer 129: 80-84. [Crossref]

110. Genotype-directed therapy for advanced non-small cell lung cancer. Post TW, ed UpToDate. Waltham, MA: UpToDate Inc. [https://www.uptodate.com] (Accessed on October 30, 2019).

Copyright: (C2019 Zhang EW. This is an open-access article distributed under the terms of the Creative Commons Attribution License, which permits unrestricted use, distribution, and reproduction in any medium, provided the original author and source are credited. 